\title{
Marble Industry Role in the Socio Economic Development of Marble Industrial Owners of District Mohmand Federal Administered Tribal Area-Pakistan
}

\author{
Sajjad Ahmad \\ Institute of Development Studies, The University of Agriculture Peshawar \\ Dr.Naushad Khan \\ Institute of Development Studies, The University of Agriculture Peshawar
}

\begin{abstract}
The study was carried out in District Mohmand in August, 2018. The major objective was, to find out marble industry role in the socio-economic development of District Mohmand. The study area consists of 7 tehsils while three tehsils namely Safi, Pandiali, Khwezai Bazai were selected on the basis of more marble industries . The total number of marble industries in these tehsils were 140, Safi 40, Pandiali 48 and Khwazia Bazai 48 while all were selected for the present study. Data were collected though questionnaire while Descriptive statistic and paired T-test were used for data analysis. The mean monthly income of the respondents after marble industry was Rs.97286 and before was Rs.49843 while mean monthly expenditure after was Rs.51714 and before was Rs.39479.Similarly the mean monthly saving after marble industrial owners was found Rs.45500 and before was Rs.10786 and the school children were found more than before. Similarly the private school number was found more than before. The monthly mean expenditure on education after marble industry was found Rs.6151 and the expenditure before was Rs.4361. Subsequently the private hospitals were found more than before. The mean monthly expenditure on health after marble industries was Rs.6501 and before was Rs.4700.All results were found highly significant at 5\% level. Majority house were found Pucca than before. The land holding size of the respondents' number was increased due to marble industries in the study area. The number of vehicles decreased due to huge investment for the industry establishment. The study recommends to fulfill the needs of the industry owners and to enhance the export of marble abroad. Transportation problem should be permanently solved for pushing the marble industries in the study area. It will be also better to decrease the govt. taxes and water availability in the study area for enhancing marble industries for generating more employment for improving their income level in the study area. Credit and marketing facilities availability also play key role in the enhancement of marble industries in the study area.
\end{abstract}

Keywords:- Role, Marble Industry, Socioeconomic Conditions, Development, Mohmand District

DOI: $10.7176 /$ IEL/9-3-01

Publication date: April $30^{\text {th }} 2019$

\section{INTRODUCTION}

Stones have been used since a long time ago. Marble derived from the ancient greek "Marmaros" Crystaline rock or shining stone. Marble is a metamorphic rock composed of re crystallized carbonate minerals (Marble Institue of America, 2007). The ancient Egyptians used stones as a permanent structure for their civilization in building pyramids and other long life buildings that still exist till now. Greek and Roman empires, as well, used stones in the construction of columns and theaters that are still considered main touristic places in most of the Mediterranean countries. Nowadays, these countries use stones and marble for external building and internal decorations for their public and private buildings. This reflects the belief that stones are the most sustainable and long living material for construction works (Zografidis . 2007). Marble has been the material of choice for monuments, temples and buildings for thousands of years. Marble has long been a symbol of tradition, luxury and extraordinary taste. Throughout Europe, the Mediterranean and the far east, marble building remain. The Ancient Greeks used fine white marble to erect some of the most iconic building in the world. The Parthenon in Athens, coliseum in Rome, Taj Mahal in India and even the white house are all fine examples of how architects, sculptors, and craftsman have used marble to create beautiful buildings throughout the ages ( Mughairi, 2013). After the ancient Greeks, the Romans started using marble slabs to clad brick and mortars buildings. It was this innovation that allowed them to erect inter marble cities, in a short time. As marble continued, to grow in popularity, quarrying methods and tools vastly improved, to allow for greater harvesting of natural marble (Ali, 2010). The top ten countries marble exporters in the world is given in table 1 .

Pakistan is rich in mineral resources, offering a great potential for economic development and prosperity. Based on available information, the country's more than 600,000 square kilometers of outcrops area sustains varied geological potential for metallic and non-metallic mineral deposits(Omair et al, 2015).Pakistan has approximately 300 billion tons of reservoirs having 30 types of marbles. The reservoirs scattered mainly in KPK, 
the tribal belt and Baluchistan. Annual export was about 33 million dollars last year ( Khan, 2015). In the recent past, explorations by government agencies and multinational mining companies have presented ample evidence of sizeable minerals deposits throughout Pakistan. Recent discoveries of a thick oxidized zone underlain by sulphide zones in the shield area of Punjab, enveloped by thick alluvial cover have opened new vistas for metallic minerals exploration. The discovery of coal deposits having over 175 billion tones of reserves at Thar in Sindh province has given an impetus to develop it as an alternative source of energy. There is vast potential for precious and dimension stones in northern parts of the country yet to be exploited at larger scales (Omair et al, 2015). Generally speaking, the marble industry is rising speedily. At the commencement of1990s, manufacturing has climbed yearly by an average of $7.3 \%$ and global business has enlarged by an average of $8.7 \%$. Internationally, marble stone excavation for the moment is anticipated at 150 million tons gross annually. Yearly manufacturing subsequent to removal of waste and cutting reach to 820 million square meters. The entire manufactured worth is predicted at $\$ 40$ billion(PASDEC, 2010).

One of the major waste generating industries is the marble quarry and production industry by which around $70 \%$ of this precious mineral resource is wasted in the mining, processing, and polishing procedures. Around $40 \%$ of marble waste is generated world widely during quarrying operations in the form of rock fragments and being dumped either in nearby empty pits, roads, riverbeds, pasturelands, agricultural fields, or landfills leading to wide spreading environmental pollution (Çelik,1996; Akbulut and Gürer, 2003). In the case of Pakistan, most of the processing units in the country are prepared with local man-made cutting machines with slight or no calibration, high electricity expenditure and eminent class manufacture. Goods of these items have discrepancy in the tiles width as high as 1 to $2 \mathrm{~mm}$ and are shape at the ends whereas international principles agree to distinct in width up to $0.5 \mathrm{~mm}$ for tiles and the edges properly cut. Goods may also be delayed or yet blocked by the miners due to diverse rationale that contain low construction for the reason that non-scientific dig up, inability of rating, meager infrastructure due to which containers cannot drag heavy tons on roads in the district. In addition, all the above reveal grounds, there is no understanding of maintenance supply at the dispensation component or at mines mostly due to financial restraints(Mansoor and Nadeem, 2012, Omair et. al, 2015).

Pakistan has massive mineral possessions as well as marble. Sandstone is tattered equally for structure rationale and development, while onyx is a partially-trans lucentand usually tattered by developing production. Accessibility to strong quality marble treasury in Pakistan, with immense magnitude and the claim of these stones in the overseas marketplace (i.e. European Union countries, Central Asian countries etc.) make this division truly massive in proportion. Recognition of PASDEC for growth marble and granite division designate government's curiosity in this division and is an optimistic/positive signal for the shareholder in this business. Marble contribute $0.008 \%$ to GDP and rank 5th among all the minerals. This shows that this industry has a great potential in Pakistan and this share can rise in future and incoming years, marble industry can rank 2nd among all minerals (Mansoor and Nadeem, 2012). Pakistan has deposits of several minerals notably coal, copper, zinc, gold, chromites, mineral salt, and bauxite. There are also varieties of precious and semi-precious minerals, including peridot, aquamarine, topaz, ruby, emerald, rare-earth minerals bastnaesite and xenotime, sphene, tourmaline, in addition to various types of quartz. Balochistan is by far the richest province in terms of mineral resources in Pakistan. Punjab has the second largest reserves of rock salt in the world, and Khyber Pakhtunkhwa $(\mathrm{KPK})$ is the richest province in terms of gem stones. Recently, vast deposits of coal have been discovered in Sindh. (Omair et al, 2015; Mansoor and Nadeem, 2012). The implementation of the First National Mineral Policy (NMP 1995) at both Federal and Provincial levels paved the way for an expansion of mining sector activity in Pakistan. The implementation, as well, proved to be a pivotal step toward attracting investment in the mining sector. Although the mining sector currently contributes less than $1 \%$ to Pakistan's GDP, recent discoveries have provided strong evidence of significant mineral deposits and a great potential for the sector to contribute to the national and local economies (PMDC, 2009)

Pakistan has a large base of industrial minerals, and the growing interest from international mining companies carries great potential for the rapid development of the sector. As the government is looking to enhance the contribution of the mining sector to Pakistan's economic development, it becomes even more imperative for the Policy to reflect developments in the global mining sector since 1995, including legal, fiscal and environmental developments. In view of these developments, a review of the NMP became necessary in order to ensure its alignment with contemporary practices, and enhance the international competitiveness of Pakistan's mining sector (Mahmood, 2011). The new policy is intended to serve as a clear and detailed representation of governments' objective of improving the international competitiveness of the mineral sector in Pakistan. NMP-2 seeks to provide the basis for addressing these and other challenges, as well as responding to important government priorities and commitments. For example, policy provisions to cater for research and development, human resource development, as well as promotion and marketing, are included in NMP-2. (Mahmood, 2011). Pakistan's economy continues to face numerous domestic and external shocks from 2007 onwards. Economic performance was affected from the devastating floods and rains, the internal security 
hazards, and the energy crisis. Majority marbles industries are working in KPK particular in Mahmand Agency which play great role in the economic development of Pakistan Seeing to its importance the present study was arranged to find out the role of marble industry in the socio-economic development of District Mahmand and to know its role in education and health care of the study area.

\section{METHODS AND MATERIAL}

The current study universe was the District Mohmand . It is situated in the North-West of Peshawar at a distance of about $80 \mathrm{~km}$. This district has a population of around 540,000 (13\% of total FATA population) and an area of 229,620 hectares (around 10\% of the total FATA area). The cultivated area is around $9 \%$ and water availability is an issue in most parts of the district. The prominent sectors include Agriculture and Minerals; Chilies, wheat, and vegetables are predominant products in Agriculture while Marble, Manganese, Quartz, etc. in Minerals. The land is fertile but water are scarce. Agriculture is rain based. Majority of the people are engaged with marble industry. It has huge reservoirs of marbles in which numerous varieties of marbles are present. Therefore District Mohmand was selected for the present study. There are 7 tehsil in District Mahmand while three tehsils Safii, Khwezai Baizai and Pandiali were selected on the basis of more marble industries. The total marble industries were 140 and all were selected for the present study. The detail is given below in table 2. The nature of the data in the current study is primary in nature. The data was collected from the owners of the marble industries working in 3 tehsils of District Mohmand. Closed ended questionnaire was designed to distribute among the sample respondents and collect data from them. Total 140 owners of marble industries were given questionnaire for the data collection. Marble industry is an independent variable, while income level is the major dependent variable that depends on marble industry. Similarly, health care and education level are dependent variables which are directly dependent on income level while indirectly dependent on marble industry. The theoretical framework is given below:

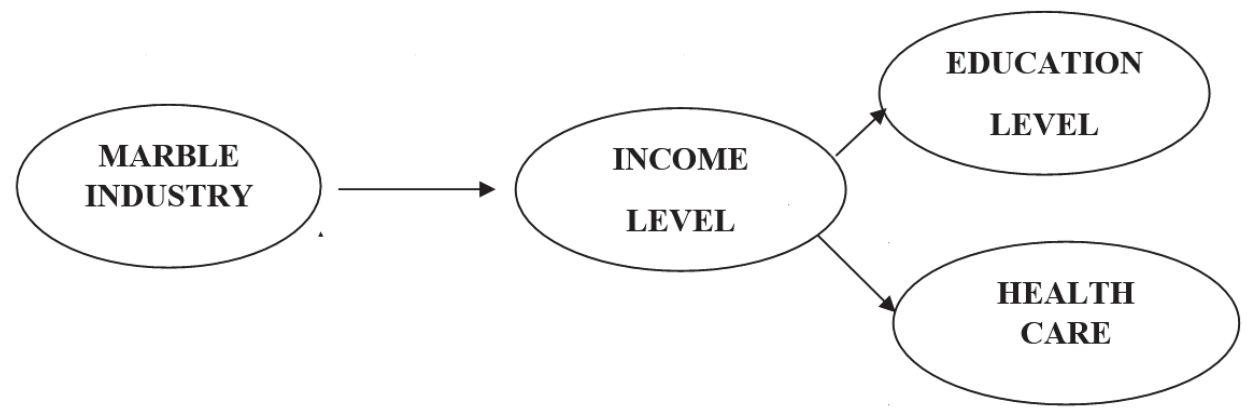

Descriptive Statistics and paired t-test were used for data analysis. Pair t-test formula explanation is given as: $t={ }_{s d}^{d}$ With $\mathrm{n}-1$ degree of freedom $\mathrm{d}$ denote the mean differences, $\mathrm{S}_{\mathrm{d}}$ denotes the standard error of mean differences.

\section{RESULTS AND DISCUSSIONS}

This section presents the socio-economic characteristics of the respondents and the empirical result of the research area. The information were tabulated, analyzed and discussed. The main points discussed in this section were the demographic and other socio-economic characteristics improved due to marble industry Table 3 reveals age wise distribution of the sampled respondents in the study area. According to table in 20-30 age category the sampled respondents frequency is $9 \%$ while in 30-40 age category the sampled respondents frequency is $27 \%$. Similarly in 40-50 age category the sampled respondents frequency is $30 \%$ and in 50-60 age category the frequency of the sampled respondents is $24 \%$ while in above 60 age category the frequency is $10 \%$. Majority respondents are present in 40-50 age categories, which is followed by 30-40 age category groups. The lowest frequency is appeared in 20-30 age category and is followed by above 60 age category in the table. The data shows that majority respondents' ages are mature and capable to run their business very well in the study area of marble industry. Table 4 indicates the literacy status of the sampled respondents in the study area. According to table the literate frequency is $44 \%$ while the illiterate frequency is $56 \%$. It shows that majority respondents are illiterate. Literacy is very important factor in the development of marble industries. The literate people very easily adopt the modern technology which play key role in marble industry improvement in the study area. The educated people' run the management system very well. They keep the record in proper way and analyze the cost and benefits in a systematic way and know the loss and benefit of the business very well. Table 5 shows the education level of the sampled respondents in the study area. According to table primary education level frequency of the sampled respondents is $6 \%$ while the Middle level frequency is $11 \%$. Similarly the frequency of the Matric level is $15 \%$. While the Intermediate level is $16 \%$ and Bachelor level is $8 \%$. Subsequently the illiterate frequency is $44 \%$ which already is mentioned in table 3 . The majority respondents' education level is 
illiterate and frequency is $44 \%$ and is followed by intermediate level whose frequency is $16 \%$. The primary education level frequency is the lowest among the education level which is followed by Bachelor level which is only $8 \%$. There are no Master level among the sampled respondents' in the study area. The data shows that the highest level do not take interest in marble industry while they try for other government permanent jobs where security of the jobs is more than the private jobs and after retirement pension is also available. Table 6 reflects the family types of the sampled respondents in the study area. According to table the frequency of the Extended family is $21 \%$ while the Joint family frequency of the sampled respondents' is $49 \%$ and similarly the frequency of the Nuclear family is $30 \%$. Majority respondents' are present in joint family which is followed by Nuclear family. Before the frequency in the extended family was more while now a day this strength is changing into joint and nuclear families in the study area. The people, in the area before was very weak economically, so they cannot afford for construction of house while now a day their income level is increasing due to marble industrialization, so they afford to make a new house for their family in the study area. Through this way the joint and nuclear family frequency is increasing day by day. The age of the before people was more so the age of the elder of the family was live long and the division of the land was late and the extended family period was run for long time. Now a day this strength has been changed into joint and nuclear families due to income and age expectancy rate in the study area. Table 7 explains the family size of the sampled respondents in the study area. About $14 \%$ of sampled respondents have the family size less than 5 persons, $39 \%$ have the family size $5-10$ persons, similarly $31 \%$ of the sampled respondents have the family size $10-15$ persons while $16 \%$ have the family size above 15 persons. Majority respondents fall in 5-10 persons family size group which is followed by 10-15 persons family size group. This group size of family is $31 \%$ while the lowest frequency falls in below 5 persons family size group and is followed by above 15 person group. The table shows that average family size is 5-10 person group. The family size composition play great role in the marble industries improvement because on one side they supply labors to marble industries while on the other side they affect the income, expenditure and saving of the family. If the independent number is more, then they improve the income level while if less, then they decrease the per capita income of the family however the number of family size also affect the per capita income of the family..

Table 8 proves the main source of income of the sample respondents in the study area. According to the table agriculture is the main source of income of $11 \%$ of the respondents, business is $16 \%$, Marble industry is the main source of income for about $57 \%$ of the sample respondents, while $16 \%$ of the respondents has other main source of income. The results prove that marble industry is the largest source of income for the sample respondents in the study area. Table 9 indicates the tenure status of the sampled respondents in the study area. About $24 \%$ of the sampled respondents are owners of the marble industries. Similarly $46 \%$ are the owner cum tenants and $30 \%$ of the respondents belong to tenant group. Highest frequency falls in the owner cum-tenants group which is followed by tenant group. Tenure status play great role in the development of marble industries. The owner and the owner cum tenant very easily get the loan from the banks while tenants have no opportunities for gaining the loan due to lack of collaterals. So the tenure status affects the business activities of the marble industries in the study area Table 10 shows the impact of marble industry on land holding size of the sampled respondents in the study area. According to table in less than 2.5 acres land category the number of respondents before the marble industry was 8 while after marble industry the frequency is zero and the change is-8. Similarly in 2.5-5 acres land category the respondent frequency before was 28 and after marble industry is 4 respondents and the change is -24 . In 5-7.5 acres land category the respondent frequency before was 48 respondents while now it is 17 respondents and the change is -31 respondents. Subsequently in 7.5-10 acres land category the number of respondents before was 39 respondents while now after marble industry, it is 63 respondents and the change is 24 respondents and positive in the study area while in more than 10 acres category the respondent number before was 17 and now it is 56 respondents after marble industry and the change is 39 respondents. The whole data of the table shows that negative change have been occurred from less than 2.5 acres land category to 5-7.5 acres land category while the positive change was occurred from7.5-10 to more than 10 acres land category in the study area. The reason of negative change is shifting of marble industrial owner to upper category land size due to income level improvement due to marble industry in the study area while the positive change is the entering of lower category land holder into higher category land holding by purchasing land due to marble industries more earning in the study area.

Table 11 indicates the marble industry impact on the Monthly income of sampled respondents in the study area. The mean income after marble industry is Rs.97286 and before was Rs.49843 while the difference is Rs.47443. The t-value is 20.195, Degree of Freedom is 139 and P.Value is .000 . The result is highly significant at 5\% level and it shows that marble industry has improved the annual average income level of the sampled respondents of the study area. It is the good sign for development in the long run. Through this methodology more industries will be established in that area and new employment will be generated which solve the problems of the unemployment of the study area. Similarly poverty will be reduced and prosperity will be occurred in the area and purchasing power of the respondents will be improved which latter on improve the other sector of the 
economy. Exports will be increased and the country balance of trade will be improved which latter on increase the balance of payment and GDP of the country while government support is required for uplifting to this sector in the study area. Table 12 indicates the marble industry impact on the monthly expenditure of sampled respondents in the study area. According to table the mean expenditure after marble industry is Rs.51714 and before was Rs.39479 and the difference is Rs.12235. The t value is 13.244 , Degree of Freedom is 139 and the P value is .000 . The result is highly significant at $5 \%$ level and it shows that marble industry has improved the income level of the sampled respondents which directly affect the expenditure of the respondents like consumption function. The consumption theory explains that when income increasing the consumption will also be increased at some level in different zone of the economic sectors. The expenditure push the demand of the commodities which further push the price of the producer which latter on improve the investment activities in the country. The table conclude that marble industry has increased the expenditure level of the sampled respondents in the study area. This expenditure increasing is the good sign for the development of a country because income increasing push the consumption while industry push the income level of the people and also affect other sector of the economy. Table 13 shows the marble industry impact on the monthly saving of sampled respondents in the study area. The mean saving after marble industry is Rs.45500 and before was Rs.107856 and the difference is Rs.34714 and the t-value is 15.273 and the Degree of freedom is 139 and the p-value is .000 . The result is highly significant at $5 \%$ level. It shows that marble industry has improved the income level of the sampled respondents in the study area which have also push saving at some level like consumption theory. This theory claim that, when income increasing, the expenditure also increasing at some proportion. Saving increasing is the good sign for the development of a country. Through saving the investment ratio in the country increasing which latter on generate the employment and solve the problems of the unemployment in the country. Similarly reduce the poverty and improve the export and GDP of the country. The study conclude that marble industry has improved the saving level of the sampled respondents in the study area while positive saving further affect the economy of the country positively which latter on make the country economy healthy and strong.

Table 14 proved that about 54 sampled respondents have kacha house structure but after marble industry it decreased to 12 respondents and the difference record was -42 respondents. Similarly about 62 respondents having Pacca house structure before marble industry and now it is 90 respondents after marble industry and the difference is 28 respondents while before marble industry about 24 respondents having semi pacca house structure and now after marble industry the respondents number is 38 respondents and the difference is 14 respondents. So the table shows that marble industries has positive impact on house construction pattern and indicate that marble industry play great role in the development of housing scheme in the study area. The marble industry improve the respondents income which enhance the purchasing power of the respondents which further affect other sectors positively. Table 15 shows that before marble industry about 23 sampled respondents have no school children while this figure decrease to 18 after marble industry. Similarly, 69 respondents have below 5 school children before marble industry which increased to 80 respondents after marble industry. While 48 sampled respondents were found to have above 5 going to school children before marble industry and 42 school going children after marble industry. It shows that marble industry has multiplied the number of going school children of the sampled respondents in the study area. It is a good sign for the development of a country because education play great role in the development of a country. The children development of reading and writing, further play great role in business activities. They do the research and solve the problems of the country which further improve the economy of the country as well the world, so every country without education can do nothing for their country development. Therefore government has opened different type school in the country. Those countries are developed very well where high level educational institutions are present. The table concludes that marble industry has improved the going children number in the study area. Table 16 shows the impact of marble industry on expenditure on education of the sample respondents in the study area. Mean expenditure on education after is Rs. 6151 and before is Rs. 4361. The mean difference is Rs.1790.. The t-value is 12.708 , degree of freedom is 139 and the p-value is .000 . The result is highly significant at $5 \%$ level and it proves that marble industry improve the income level of the respondent which indirectly increase the expenditure of education of the sample respondents in the study area. Table 17 reveals the status of school attended by sampled respondents' children in the study area. There were about 43 sampled respondents who admitted their children in government school before marble industry while the frequency was 35 after marble industry with a difference of -8. Similarly 53 sampled respondents' children read in semi government schools before marble industry and now this figure rises to 61 sampled respondents after marble industry and the difference is 8 while about 44 respondents children were admitted in Private school before and after marble industry with no difference. The table data shows that after marble industry majority respondents' children were found in high status school in the study area. So it is also a good sign for the improvement of the study area. The main reason is that the people income is more now than before after marble industries. There purchasing power due to marble industry were improved; now therefore they send their children to high status schools instead of government schools. 
Table 18 shows the difference of the vehicles before and after marble industry. About 7 sampled respondents before marble industry having no vehicle while after marble industry this figure reach to 43 with a difference of -36 . Similarly 62 of the sampled respondents have one vehicle before and 68 respondents after marble industry and the difference is -6 . There were 58 sampled respondents having two vehicles before marble industry and 29 after marble industry. While 13 sampled respondents have three vehicles before marble industry but this figure declined to zero after marble industry. Before 7 respondents have no vehicle while now 43 respondents have no vehicle in the study area. In the second category the number of vehicle is more than before while in the third and fourth categories the vehicles number is less than before. It indicates that the respondents now invest more in marble industries than vehicles and they highly focus on marble industry business while before they were involved in the transportation in the study area, so marble industry has affect the pattern of the business in the study area. Table 19 indicates the type of hospital attendance by sampled respondents' family member in the study area. According to table about 72 sampled respondents family member attended government hospitals but the figure drops to 15 respondents after marble industry and the difference is -5 . Similarly 34 respondents attend semi government hospitals before marble industry and now 84 respondents after the marble industry with a difference of 50 while 34 respondents attend private hospitals before marble industry and now 41 visit after marble industry with a difference of 7 . The table data shows that due to high income by marble industry the sampled respondents' hospital status was changed and now they also visits the high status hospitals in the study area. It is also a good sign for the study area development because due to income level increasing, they visit the high hospitals for controlling the diseases in the study area. Through high demand hospital services were improved and the number of jobs was also increased due to investment in health services. Before they were poor and they cannot afford the privates hospital charges while now they afford the charges due to their income level increasing by marble industry.

Table 20 shows the impact of marble industry on expenditure on health care of the sample respondents in the study area. The mean expenditure on health after is Rs.6501 and before is Rs.4700 while the difference is Rs.1801. The t-value is 10.258 , degree of freedom is 139 and the p-value is found .000 . The result is highly significant at 5\% level which proves that marble industry has positive effect on income level of the sampled respondents which indirect increase the expenditure on health of the sample respondents in the study area. Table 21 indicates the problems faced by sampled respondents in marble industries improvement in the study area. About $100 \%$ of the sampled respondents faced the problems of government taxes, skill labor, modern technology, marketing and securities, credit availability while about $92 \%$ respondents faced the problem of proper inputs in the study area. Similarly $85 \%$ respondents face the problem of transportation while $71 \%$ respondents also claim the water availability problem in the study area. The mentioned problems are the hurdles for enhancing marble industry in the study area, so its solution is required for enhancing marble industrialization in future in the study area.

\section{CONCLUSION AND RECOMMENDATIONS}

The study finally concluded that after marble industry the level of income of the sample respondents were increased which play great role in expenditure, saving, educational institution availability and health services center availability in the study area. Similarly due to marble industry the income level of the people increased which further developed the house structure of the respondents while house structure shifted from kacha to Pacca house in the study area. So the full story of research indicates that marble industries has play great role in employment generation, income level increasing and in pushing the business activities such as agriculture, educational institution, health care center in the study area while this sector have also create pollution in the study area which have not been mentioned in the results section of the paper because it was not the objective of the present study while it is recommended for further study of other students. On the basis of problems, following recommendation were suggested for the enhancement of marble industries for pushing the economic and socio condition of the study area. For protection marble industry owners industrial reforms should be made; The government should enhance the transportation facility for the easy availability of the raw material; The government should give incentives on easy terms to the industry owners; Credit should be provided to marble industrial owners in the study area; Marble industrial owners should be exempted from the government tax for uplifting to this sector in the study area; Water availability facilities must be assured in the study area; Training institution should be established in the study area for covering the deficiency of skill labour; Free electricity should be provided to marble industry owner for uplifting marble industry in the study area.

\section{ACKNOWLEDGEMENT}

High tribute is given to institute of development studies and particular to Dr.Himayatullah Khan and board of studies members who played great role in the development of this paper. The members give valuables suggestion for improvement while Muhammad Kaleem, Fazal Hanan and Shah Fahad also play great role in this paper development and funding 


\section{CONTRIBUTION OF THE AUTHORS}

The idea was created by Sajjad Ahmad Student of M.Sc(Hons) Rural Development, Institute of Development Studies and supervised by Dr.Naushad Khan Assistant Professor Institute of Development studies. The paper was prepared from student thesis. No fund was provided to student for data collection because his village was nearest to the study area, so on self finance he conducted the study and complete to this paper.

\section{REFFERENCES}

1. Akbulut H. and C.,Gürer (2003). "The Environmental Effects of Waste Marble and Possibilities OfUtilization and Waste Minimization by Using in the Road Layers". Proceeding of the fourth national marble symposium, Afyonkarahisar, December:371-8, Turkish.

2. Ali, A.D (2010). “Technical Journal of Precious Stones” Vol.101, pp. 115.

3. Çelik, M. Y. (1996). "Recycling of Waste Marble". M. Sc.Thesis, AfyonKocatepe University, Natural Science Institute, Department of Mining Engineering, Afyonkarahisar, Turkish.

4. Mansoor, Y. and S.,Nadeem, S. (2012), Pakistan Marble Industry Challenges: Opportunities for Chinain Pakistan, Journal of Independent Studies and Research - MSSE Volume 10,No. 1

5. Mehmood, A. (2011), Bringing mining to Pakistan to international standards, Pakistan mining groups.

6. Mughairi. H.S, (2013), "History of Architect and Sculptures" Vol. 02, pp. 112.

7. Omair, M., Noor, S., Hussain, I., Maqsood. S., Khattak, B., Akhtar. A. \&UlHaq, I. (2015), Sustaible development tool for Khyber Pakhtunkhwa's dimension stone industry, Technical Journal, University of Engineering and Technology (UET) Taxila, Pakistan Vol. 20(SI) No.II(S)

8. Tahir. A.K, 2015, "An endeavor for Tolerance, Peace and development" : 97-98

9. Zografidis (2007) "Sustainability of the dimension stone industry in Zimbabwe" Vol.3:112

10. The Marble Institute of America (2007), “Annual Regional Alliance Report”:215-216

11. PASDEC (2010). "Pakistan Stone Development Company”Business Recorder Report(2010)

12. PMDC (2009), "Pakistan Mineral Development Corporation" Annual Report-2009

13. Sleuwaegen, L. \& Goedhuys, M. 2002. Growth of Firms in Developing countries, evidence from Co'te d'Ivoire. Journal of Development Economics, 68, 117-135.

14. Moore, Mick. 2001. "Political Underdevelopment. What Causes 'Bad Governance'?"Public Management Review 3(3): 385-418.

15. Auty, Richard M., and Indra de Soysa, eds. 2006. Energy, Wealth and Governancein the Caucasus and Central Asia: Lessons Not Learned. Routledge.

16. Mathleena Kniivila. (2007), Industrial Development and Economic Growth : Implications for Poverty Reduction and Income Inequilty.

Table 1 Top Ten Countries Marble Exporter in the World.

\begin{tabular}{|l|c|c|}
\hline Name of Countries & Total Income per Annum & Percentage of Marble Exports \\
\hline Turkey & 872 million dollars & $38.3 \%$ \\
\hline Italy & 377 million dollars & $16.6 \%$ \\
\hline Spain & 205.3 million dollars & $9 \%$ \\
\hline Egypt & 142.5 million dollars & $6.3 \%$ \\
\hline Greece & 131.8 million dollars & $5.8 \%$ \\
\hline Iran & 102.2 million dollars & $4.5 \%$ \\
\hline Portugal & 69.1 million dollars & $3 \%$ \\
\hline Pakistan & 57.3 million dollars & $2.5 \%$ \\
\hline India & 29,4 million dollars & $1.3 \%$ \\
\hline United States & 28.8 million dollars & $1.3 \%$ \\
\hline
\end{tabular}

Table 2 Sampled Respondents Frequency in Different Tehsil of District Mahmand

\begin{tabular}{|l|c|c|}
\hline Tehsil & Frequency & Percentage \\
\hline Safi & 44 & 32 \\
\hline Khwezai\&Baizai & 48 & 34 \\
\hline Pandiali & 48 & 34 \\
\hline Total & 140 & 100 \\
\hline
\end{tabular}

Source:- Field Survey 2018 
Table 3 Age Wise Distribution of the Sampled Respondents in the Study Area.

\begin{tabular}{|l|c|c|}
\hline Age Categories (Years) & Frequency & Percentage \\
\hline $20-30$ & 12 & 09 \\
\hline $30-40$ & 38 & 27 \\
\hline $40-50$ & 42 & 30 \\
\hline $50-60$ & 34 & 24 \\
\hline Above 60 & 14 & 10 \\
\hline Total & 140 & 100 \\
\hline
\end{tabular}

Source:- Field Survey 2018

Table 4 Literacy Status of the Sampled Respondents in the Study Area.

\begin{tabular}{|l|c|c|}
\hline Literacy Status & Frequency & Percentage \\
\hline Literate & 61 & 44 \\
\hline Illiterate & 79 & 56 \\
\hline Total & 140 & 100 \\
\hline
\end{tabular}

Source:- Field Survey 2018

Table 5 Education Level of the Sampled Respondents in the Study Area.

\begin{tabular}{|l|c|c|}
\hline Education Level & Frequency & Percentage \\
\hline Primary & 08 & 6 \\
\hline Middle & 16 & 11 \\
\hline Matric & 21 & 15 \\
\hline Intermediate & 22 & 16 \\
\hline Bachelor & 12 & 8 \\
\hline Illiterate & 61 & 44 \\
\hline Total & 140 & 100 \\
\hline
\end{tabular}

Source:- Field Survey 2018

Table 6 Family Types, of the Sampled Respondents in the Study Area.

\begin{tabular}{|l|c|c|}
\hline Family Type & Frequency & Percentage \\
\hline Extended & 30 & 21 \\
\hline Joint & 68 & 49 \\
\hline Nuclear & 42 & 30 \\
\hline Total & 140 & 100 \\
\hline
\end{tabular}

Source:- Field Survey 2018

Table 7 Family Size of the Sampled Respondents in the Study Area.

\begin{tabular}{|l|c|c|}
\hline Family Size & Frequency & Percentage \\
\hline Below 5 & 20 & 14 \\
\hline $5-10$ & 54 & 39 \\
\hline $10-15$ & 44 & 31 \\
\hline Above 15 & 22 & 16 \\
\hline Total & 140 & 100 \\
\hline
\end{tabular}

Source:- Field Survey 2018

Table 8 Main Source of Income of the Sampled Respondent In the Study Area

\begin{tabular}{|c|c|c|}
\hline Main Sources of Income & Frequency & Percentage \\
\hline Agriculture & 15 & 11 \\
\hline Business & 23 & 16 \\
\hline Marble Industry & 79 & 57 \\
\hline Others & 23 & 16 \\
\hline Total & 140 & 100 \\
\hline
\end{tabular}

Source:- Field Survey 2018 
Table 9 Tenure Status of the Sampled Respondents in the Study Area.

\begin{tabular}{|l|c|c|}
\hline Tenure status & Frequency & Percentage \\
\hline Owner & 33 & 24 \\
\hline Owner- cum tenants & 65 & 46 \\
\hline Tenants & 42 & 30 \\
\hline Total & 140 & 100 \\
\hline
\end{tabular}

Source:- Field Survey 2018

Table 10 Impact of Marble Industry on Land Holding Size of the Sampled Respondents in the Study Area

\begin{tabular}{|l|c|c|c|}
\hline Land Holding (Acres) & Frequency After & Frequency Before & Difference \\
\hline Less than 2.5 & 0 & 8 & -8 \\
\hline $2.5-5$ & 4 & 28 & -24 \\
\hline $5-7.5$ & 17 & 48 & -31 \\
\hline $7.5-10$ & 63 & 39 & 24 \\
\hline More than 10 & 56 & 17 & 39 \\
\hline Total & 140 & 140 & 00 \\
\hline
\end{tabular}

Source:- Field Survey 2018

Table 11 Marble Industry Impact on the Monthly income of Sampled Respondents in the Study Area

\begin{tabular}{|l|l|c|c|c|c|c|}
\hline $\begin{array}{l}\text { Mean Income After Marble } \\
\text { Industry }\end{array}$ & $\begin{array}{l}\text { Mean Income Before Marble Differences } \\
\text { Industry }\end{array}$ & T.Value & D.F & P.Value \\
\hline Rs.97286 & Rs.49843 & Rs.47443 & 20.195 & 139 & .000 \\
\hline
\end{tabular}

Source: Field Survey 2018

Table 12 Marble Industry Impact on the Monthly Expenditure of Sampled Respondents in the Study Area

\begin{tabular}{|l|c|c|c|c|c|}
\hline $\begin{array}{c}\text { Mean Expenditure After } \\
\text { Marble Industry }\end{array}$ & $\begin{array}{c}\text { Mean Expenditure Before } \\
\text { Marble Industry }\end{array}$ & Differences & D.F & $\begin{array}{c}\text { T- } \\
\text { Value }\end{array}$ & P.Value \\
\hline Rs.51714 & Rs.39479 & Rs.12235 & 13.244 & 139 & .000 \\
\hline
\end{tabular}

Source:- Field Survey 2018

Table 13 Marble Industry Impact on the Monthly Saving of Sampled Respondents in the Study Area

\begin{tabular}{|l|l|l|l|l|l|l|}
\hline $\begin{array}{l}\text { Mean Saving After Marble } \\
\text { Industry }\end{array}$ & $\begin{array}{l}\text { Mean Saving Before Marble } \\
\text { Industry }\end{array}$ & Differences & T.Value & D.F & P.Value \\
\hline Rs.45500 & Rs.10786 & 34714 & 15.273 & 139 & .000 \\
\hline
\end{tabular}

Source: Field Survey

Table 14 House Structure of the Sampled Respondents Before and After Marble industry

\begin{tabular}{|l|c|c|c|}
\hline House Structure & Frequency After & Frequency Before & Difference \\
\hline Kacha & 12 & 54 & -42 \\
\hline Pacca & 90 & 62 & 28 \\
\hline Semi Pacca & 38 & 24 & 14 \\
\hline Total & 140 & 140 & 00 \\
\hline
\end{tabular}

Source: Field Survey 2018

Table 15 Number of School Children of the Sampled Respondents Before and After Marble Industry

\begin{tabular}{|l|c|c|c|}
\hline Number of School children & Frequency After & Frequency Before & Difference \\
\hline NIL & 18 & 23 & -5 \\
\hline Below 5 & 80 & 69 & 11 \\
\hline Above 5 & 42 & 48 & -6 \\
\hline Total & 140 & 140 & 00 \\
\hline
\end{tabular}

Source:- Field Survey 2018 
Table 16 Marble Industry Impact on Monthly Expenditure on Education of the Sampled Respondent in the Study Area

\begin{tabular}{|l|l|c|c|c|c|}
\hline $\begin{array}{l}\text { Mean Expenditure on Education } \\
\text { After }\end{array}$ & $\begin{array}{l}\text { Mean Expenditure on Education } \\
\text { Before }\end{array}$ & Difference & $\begin{array}{c}\text { T- } \\
\text { Value }\end{array}$ & $\begin{array}{c}\text { D.F } \\
\text { P- } \\
\text { Value }\end{array}$ \\
\hline 6151 & 4361 & 1790 & 12.708 & 139 & .000 \\
\hline
\end{tabular}

Field Survey-2018

Table 17 Status of School Attended by Sampled Respondent Children Before and After Marble Industry in the Study Area

\begin{tabular}{|l|c|c|c|}
\hline Number of school children & Frequency After & Frequency Before & Difference \\
\hline Govt & 35 & 43 & -8 \\
\hline Semi Govt & 61 & 53 & 8 \\
\hline Private & 44 & 44 & 0 \\
\hline Total & 140 & 140 & 0 \\
\hline
\end{tabular}

Source:- Field Survey 2018

Table 18 Number of Vehicles of the Sampled Respondents in the Study Area Before and After Marble Industry

\begin{tabular}{|l|c|c|c|}
\hline Number of vehicle & Frequency After & Frequency Before & Difference \\
\hline Nil & 43 & 07 & 36 \\
\hline One & 68 & 62 & 06 \\
\hline Two & 29 & 58 & -29 \\
\hline Three & 00 & 13 & -13 \\
\hline Total & 140 & 140 & 00 \\
\hline
\end{tabular}

Source: Field Survey 2018

Table 19 Status of Hospitals Attendance by Family Member of the Sampled Respondents' Before and After Marble Industry.

\begin{tabular}{|l|c|c|c|}
\hline Type of Hospitals & Frequency After & Frequency Before & Difference \\
\hline Govt & 15 & 72 & -57 \\
\hline Semi Govt & 84 & 34 & 50 \\
\hline Private & 41 & 34 & 7 \\
\hline Total & 140 & 140 & 00 \\
\hline
\end{tabular}

Source: Field Survey 2018

Table 20 Marble Industry Impact on Monthly Expenditure on Health Care of the Sampled Respondent in the Study Area

\begin{tabular}{|l|c|c|c|c|c|}
\hline $\begin{array}{l}\text { Mean Expenditure on Health } \\
\text { After }\end{array}$ & $\begin{array}{c}\text { Mean Expenditure on Health } \\
\text { Before }\end{array}$ & Difference & $\begin{array}{c}\text { T- } \\
\text { Value }\end{array}$ & $\begin{array}{c}\text { D.F } \\
\text { P- } \\
\text { Value }\end{array}$ \\
\hline 6501 & 4700 & 1801 & 10.258 & 139 & .000 \\
\hline
\end{tabular}

Source:- Field Survey 2018

Table 21 Problems Faced by Sampled Respondents in Marble Industries Improvement in the Study Area

\begin{tabular}{|l|l|c|c|}
\hline S.No & Problems & Frequency & Percentage \\
\hline 01 & Govt.Tax & 140 & 100 \\
\hline 02 & Skill Labour & 140 & 100 \\
\hline 03 & Modern Technology & 140 & 100 \\
\hline 04 & Lack of proper inputs & 130 & 92 \\
\hline 05 & Transportation & 120 & 85 \\
\hline 06 & Marketing & 140 & 100 \\
\hline 07 & Security & 140 & 100 \\
\hline 08 & Water Availability & 100 & 71 \\
\hline 09 & Credit & 140 & 100 \\
\hline 10 & Electricity Bills & 140 & 100 \\
\hline
\end{tabular}

Source: Field Survey 2018 